\title{
PARIWISATA : \\ SEBAGAI SALAH SATU UPAYA MEMPEROLEH DEVISA BAGI PEMERINTAH INDONESIA
}

\author{
Anto Kustanto \\ Fakultas Hukum Universitas Wahid Hasyim \\ antokustanto@unwahas.ac.id
}

\begin{abstract}
ABSTRAK
Pembangunan nasional dilaksanakan dengan sasaran salah satunya memantapkan perolehan devisa negara sebagai kerangka landasan ekonomi Indonesia. Pada tataran perundang-undangan sebagai pelaksanaan dari UUD 1945, kehendak untuk melaksanakan pembangunan nasional dengan segenap daya dan dana yang dimiliki digambarkan dengan nyata. Semisal, Undang-Undang No.25 Tahun 2004 tentang Perencanaan Pembangunan Nasional dengan jelas menyebutkan bahwa pembangunan nasional Indonesia merupakan upaya oleh segenap komponen bangsa Indonesia dalam rangka mencapai tujuan bernegara. Hakekat dari pembangunan itu terletak pada masalah pembaruan cara berfikir dan sikap hidup, terkait dengan perlunya perubahan sikap mental seluruh rakyat Indonesia untuk mengantisipasi pembangunan nasional melalui sektor pariwisata. Oleh karena itu, pemerintah dalam hal ini kementrian pariwisata dan kebudayaan perlu mengupayakan tersedianya buku-buku terkait dengan dunia kepariwisataan, sebagaimana amanat Undang-Undang Nomor.10 tahun 2009 tentang Kepariwisataan, khususnya melalui Pasal 4 : "kepariwisataan merupakan pilar strategis dalam mencapai tujuan pembangunan nasional". Untuk itu, dalam rangka mendorong investasi dan pendanaan ekonomi sektor pariwisata di Indonesia agar menarik dan bermanfaat, kiranya perlu memperhatikan 3 (3) hal yakni : pertama, pembangunan sektor pariwisata harus mendukung pendekatan sinergis yang menyumbang pada pencapaian sasaran ekonomi (perolehan devisa), sosial dan lingkungan secara bersamaan. Contohnya, kebijakan melindungi serta merehabilitasi lahan obyek wisata, seperti mempercantik lingkungan sekitar. Ke $\boldsymbol{d u a}$, laporan pencapaian program strategis dari Kementrian terkait ( pariwisata) dalam upaya memenangkan pasar di era industri 4.0 demi mencapai target 20 juta wisatawan manca negara di tahun 2019 ini. The more digital, the more proffesional. The more digital, the more global, hal itulah yang merubah industri pariwisata, sehingga perilaku wisatawan terlihat ketika search and share $70 \%$ sudah melalui digital, kuncinya terletak pada sumber daya manusia.
\end{abstract}

Kata Kunci : Undang - Undang Nomor.10 tahun 2009 tentang Pariwisata. 


\section{A. Pendahuluan.}

Ekonomi Indonesia bersifat terbuka, artinya ada peran penting tentang besarnya peran yang dimainkan oleh sektor baik terkait secara langsung atau tidak dengan ekonomi bangsa-bangsa lain, seperti hubungan perdagangan barang dan jasa, penanaman modal. Tetapi sektor pariwisata serta sistem moneter dan anggaran juga berlaku bagi perekonomian nasional, maka hal itu menyebabkan keterbukaaan ekonomi nasional tersebut.

Pembangunan nasional dilaksanakan dengan sasaran salah satunya memantapkan perolehan devisa negara sebagai kerangka landasan ekonomi Indonesia. Pada tataran perundang-undangan sebagai pelaksanaan dari UUD 1945, kehendak untuk melaksanakan pembangunan nasional dengan segenap daya dan dana yang dimiliki digambarkan dengan nyata. Semisal, Undang-Undang No.25 Tahun 2004 tentang Perencanaan Pembangunan Nasional dengan jelas menyebutkan bahwa pembangunan nasional Indonesia merupakan upaya oleh segenap komponen bangsa Indonesia dalam rangka mencapai tujuan bernegara.

Hakekat dari pembanguan itu terletak pada masalah pembaruan cara berfikir dan sikap hidup, terkait dengan perlunya perubahan sikap mental seluruh rakyat Indonesia untuk mengantisipasi pembangunan nasional melalui sektor pariwisata. Sebab, pariwisata di Indonesia merupakan sektor ekonomi penting bagi Indonesia, dimana pada tahun 2009 pariwisata menempati urutan ke tiga dalam hal penerimaan devisa setelah komoditi minyak dan gas bumi serta minyak kelapa sawit. Berdasarkan data tahun 2016, jumlah wisatawan manca negara yang datang ke Indonesia sebesar 11.525 .963 juta lebih atau tumbuh $10,79 \%$ dibandingkan tahun sebelumnya. ${ }^{12}$ Hal itu tidak ternafikan, sebab untuk kawasan Asia bahkan mungkin dunia Indonesia memiliki objek wisata paling lengkap karena hutan tropik negara kita diakui sebagai world heritage. Potensi keunikan ini jika lebih dikembangkan secara profesional bukan tidak mungkin akan menjadi

12 Kompas, "Strategi Menyasar Pasar Millenial”, Maret 2019. Hal.18 
asset wisata yang luar biasa dan dapat menjadi salah satu sumber perolehan devisa bagi negara Indonesia.

Membangun wawasan dan kesadaran masyarakat terhadap pengembangan kepariwisataan di Indonesia, pemerintah sudah seharusnya untuk memberdayakan daerah-daerah yang tentu membutuhkan sarana. Salah satu sarana efektif adalah menambah wawasan tentang kepariwisataan melalui buku-buku panduan upaya menjaga aset wisata daerah. Oleh karena itu, pemerintah dalam hal ini kementrian pariwisata dan kebudayaan perlu mengupayakan tersedianya buku-buku terkait dengan dunia kepariwisataan, sebagaimana amanat Undang-Undang Nomor.10 tahun 2009 tentang Kepariwisataan, khususnya melalui Pasal 4 : "kepariwisataan merupakan pilar strategis dalam mencapai tujuan pembangunan nasional".

Melalui berbagai paparan pada paragraf-paragraf di atas, maka kiranya dapat diambil sebuah tema pembahasan yakni : "Pariwisata : sebagai salah satu upaya memperoleh Devisa bagi Pemerintah Indonesia".

\section{B. PEMBAHASAN.}

Perkembangan kepariwisataan Indonesia selama beberapa tahun terakhir menunjukkan peningkatan sangat signifikan dibandingkan awal dekade tahun 2000. Peran seluruh pemangku kepentingan memberi kontribusi sangat berarti dalam pengembangan ini, baik yang berada di dalam maupun di luar negeri.

Sebagai negara kepulauan yang luas, daya tarik wisata Indonesia sangat kompetitif, Indonesia memiliki lingkungan alam lebih lengkap dibanding dengan negara lain dan selalu ditemukan tempat-tempat baru untuk menarik wisatawan. Namun, perlu disadari bahwa kedatangan wisatawan ke sebuah lokasi sangat tergantung dari kemudahan mencapainya, selain itu juga kenyamanan yang diperoleh dari perjalanan wisata itu. Sehingga, pelayanan menjadi penting untuk mendukung pengembangannya. Semisal, kesopanan - keramah tamahan kebersihan atau kesehatan menjadi prioritas perhatian selama mengelola kunjungan wisatawan tersebut. Pemahaman mengenai aspek ini kiranya perlu benar-benar dihayati oleh pemangku kepentingan apabila dikehendaki dunia kepariwisataan Indonesia lebih baik. Tujuannya, supaya semua pelaku 
kepariwisataan mengerti apa yang harus dalam mengembangkan destinasi termasuk sumber daya manusia. Dengan demikian, kerja bersama memajukan pariwisata Indonesia akan menjadi sebuah kesepakatan menggunakan pengertianpengertian dan pemahaman-pemahaman yang sama. Platform itu diharapkan dapat terwujud setidaknya untuk jangka panjang, dengan tetap memperhatikan kondisi setiap daerah walaupun setiap daerah mesti berlainan.

Menurut Salah Wahab dalam bukunya yang berjudul An Introduction On Tourism Theory sebagaimana dikutip oleh Oka.A.Yoeti, batasan pariwisata hendaknya memperhatikan anatomi dari gejala-gejala terdiri dari 3 (tiga) unsur yaitu : orang yang melakukan perjalanan pariwisata (human), daerah atau ruang lingkup tempat melakukan perjalanan (space), penggunaan waktu selama perjalanan dan tinggal di daerah tujuan wisata ( time). ${ }^{13}$ Ke tiga unsur tersebut kiranya memaknai pariwisata sebagai suatu aktivitas manusia yang dilakuan secara sadar dan mendapatkan pelayanan secara bergantian diantara orang-orang dalam suatu negara itu sendiri/di luar negeri, meliputi pendiaman orang-orang dari daerah lain untuk sementara waktu mencari kepuasan yang beraneka ragam rasanya, sehingga pariwisata bisa menajdi salah satu jenis industri baru dimana mampu mempercepat pertumbuhan ekonomi serta penyediaan lapangan kerja, peningkatan penghasilan, standard hidup disamping menstimulasi sektor-sektor produtif lainnya. Demikian pula Mr.Herman V. Schulard dalam Oka A. Yoeti yang mengatakan, pariswisata adalah sejumlah kegiatan terutama terkait dengan perekonomian secara langsung terhubung melalui masuknya orang-orang asing, maka timbul lalu-lintas peredaran devisa dari satu negara ke negara lain. ${ }^{14}$ Sebab, kunjungan wisatawan manca negara akan menukarkan mata uang negara asal mereka dengan mata uang negera yang mereka kunjungi. Sehingga, valuta asing ditukarkan dengan mata negara lain hal itu merupakan sebuah devisa.

Tiga tahun terakhir kita selalu diingatkan bahwa pertumbuhan ekonomi Indonesia akan sangat ditentukan oleh faktor lain - selain dari faktor pertumbuhan ekspor dan investasi karena belanja pemerintah dan konsumsi domestik dipercaya

\footnotetext{
${ }^{13}$ Oka A.Yoeti, Pengantar Ilmu Pariwisata", Bandung, PT.Angkasa, 1998.hal.108

${ }^{14}$ Idem.hal. 112
} 
belum dapat memberikan kontribusi yang kuat. Untuk itu, Arief Yahya selaku Menteri Pariwisata termuat dalam harian Republika menyakini dengan kondisi pertumbuhan ekonomi Indonesia tersebut, maka sudah saatnya sektor pariwisata mengambil peran dalam menopang pertumbuhan melalui perolehan devisa. ${ }^{15}$ Apalagi di era revolusi industri ini, ketika tahun 2018 telah usai dengan segala harapan dan cita-cita yang harus diperjuangkan. Hari baru di 2019 menyiratkan semangat untuk mewujudkan harapan dan cita-cita tertunda di 2018, secara umum dalam pembangunan dan pengembangan khususnya pariwisata masuk ke masa revolusi industri 4.0 akan dijajaki. Revolusi industri adalah salah satu sejarah terbesar di dunia, tidak dapat dipungkiri bahwa kehidupan kita tidak dapat lepas dari benda dan alat yang digunakan untuk mempermudah aktivitas dan pekerjaaan setiap manusia, dimana hal tersebut adalah hasil dari revolusi industri itu.

Keadaan demikian, maka di dalam mendorong sektor pariwisata harus ditekankan pentingnya perkembangan teknologi. Namun, dalam penerapan menuju Pariwisata 4.0 dibutuhkan unsur lain, salah satunya adalah generasi millenial yang sudah berkompeten. Sebab, menurut hasil survei yang dilakukan Assosiasi Penyelenggara Jasa Internet (APJII) Generasi Milleneal menjad paling dominan dalam penggunaan internet, juga generasi itu lebih suka menghabiskan waktu dan materi untuk tamasya. Artinya, pemanfaatan media dan hubungan masyarakat dengan internet adalah pilihan tepat dan praktis untuk promosi potensi pariwisata yang ada di seluruh tanah air Indonesia, memang teknologi digital pada pariwisata digunakan untuk mempermudah wisatawan dalam melakukan seamless customer experience dalam mencari look, memesan (book), dan membayar (pay) layanan wisata, sambil terus berharap pembangunan infrastruktur tetap diupayakan oleh pemerintah selaku pemangku kebijakan. Adanya metode di atas, menimbulkan tren sharing economic di sektor pariwisata, disamping itu membuat cara menjadi lebih efisien karena saling berbagi dalam memanfaatkan asset (resources).

Potensi sektor pariwisata untuk menopang ekonomi Indonesia akan terus tumbuh. Apalagi seiring pesatnya promosi meningkatkan jumlah kunjungan

${ }^{15}$ Arief Yahya, "Gebyar Pesona Budaya Indonesia”, Republika, 22-2-2019. 
wisatawan asing ke Indonesia. Karena, pariwisata untuk Indonesia menjadi pengahasil terbesar devisa yang saat ini mengalahkan minyak bumi- gas dan batu bara, apalagi dalam Undang-Undang No.10 tahun 2009 tentang pariwisata. Pasal 4 dengan jelas memberikan tujuan kepariwisataan, yakni : meningkatkan pertumbuhan ekonomi - meningkatkan kesejahteraan rakyat - menghapus kemiskinan - mengatasi pengangguran - melestarikan alam, lingkungan dan sumber daya - memajukan kebudayaan - mengangkat citra bangsa - memupuk rasa cinta tanah air - memperkokoh jati diri dan kesatuan bangsa serta mempererat persahabatan antar bangsa. Untuk itu, dalam rangka mendorong investasi dan pendanaan ekonomi sektor pariwisata di Indonesia agar menarik dan bermanfaat, kiranya perlu memperhatikan 3 (3) hal yakni : pertama, pembangunan sektor pariwisata harus mendukung pendekatan sinergis yang menyumbang pada pencapaian sasaran ekonomi (perolehan devisa), sosial dan lingkungan secara bersamaan. Contohnya, kebijakan melindungi serta merehabilitasi lahan obyek wisata, seperti mempercantik lingkungan sekitar. Ke $\boldsymbol{d u a}$, laporan pencapaian program strategis dari Kementrian terkait ( pariwisata) dalam upaya memenangkan pasar di era industri 4.0 demi mencapai target 20 juta wisatawan manca negara di tahun 2019 ini, dengan menyasar generasi millenial yang saat ini mencapai 50\% dari keseluruhan wisatawan inbound ke Indonesia.

The more digital, the more proffesional. The more digital, the more global, hal itulah yang merubah industri pariwisata, sehingga perilaku wisatawan terlihat ketika search and share $70 \%$ sudah melalui digital, kuncinya terletak pada sumber daya manusia. Sebagaimana diungkapan oleh Noviani Karina Putri ${ }^{16}$ peneliti Center for Indonesian Policy Studies (CPIS) bahwa Indonesia akan menyongsong bonus demografi pada 2030. Melimpahnya jumlah penduduk usia produktif tentu merupakan hal yang harus dimanfaatkan untuk meningkatkan capaian-capaian positif diberbagai bidang. Namun, jumlah penduduk usia produtif saja tidak cukup untuk memaksimalkan bonus demografi, maka penguasaan teknologi juga harus ditingkatkan untuk mendukung upaya tersebut.

\footnotetext{
${ }^{16}$ Noviani Karina Putri, "Memanfaatkan Media Digital untuk Kemajuan Pariwisata”, Warta Ekonomi, Edisi Kamis, 4/2018. hal.9
} 
"Why build dinasty when can created ecosystem" sering terdengar pada stratup berbasis teknologi ?, karena teknologi (internet) merupakan sebuah media promosi tepat bagi setiap stakeholder. Tetapi bagaimana pemerintah dapat melakuan kerja sama baik dengan masyarakat lokal dan startup digital nasional maupun internasional, maka sekarang pemerintah c/q kementrian pariwisata dalam menghadapi perkembangan tersebut (digital) menerapkan strategi $3 \mathrm{C}$ yakni : Confront (melawan), Compete (bersaing/berkompetisi), Cooperate (bekerjasama). Namun, walaupun pada tahun 2018 target 17 juta wisman meleset, kemungkinan terbesar tercapai 16 juta wisman sehingga dapat diproyeksikan untuk target devisa mencapai USD 17,6 millar dengan perhitungan pencapaian 16 juta wisman dikalikan rata-rata pengeluaran perkunjungan. Hal itu bukan tanpa alasan, sebab di tahun 2018 World Travel \& Tourism Council (WTTC) menempatkan Indonesia di posisi ke-9 negara dengan pertumbuhan wisman tercepat di dunia nomor 3 (tiga) di Asia dan nomor 1 (satu) di Asia Tenggara dengan kunjungan wisman ke Indonesia yang tumbuh $22 \%$.

Di tahun 2019 ini, pemerintah nampak mentarget mendatangkan wisatawan 20 juta. Untuk mencapai target tersebut kementrian pariwisata telah mengeluarkan berbagai macam regulasi yang memudahkan wisman untuk berkunjung ke Indonesia, beberapa aturan pada undang-undang sebelumnya dan dianggap menghambat atau memberikan ketidak-nyamanan bagi turis asing sekarang mulai diganti baru. Contohnya : pemerintah menghapus kebijakan tentang CAIT (Clearance approval for Indonesia Territory). Disamping itu, melalui Peraturan Presiden No.104 tahun 2015 tentang Fasilitas Bebas Visa Kunjungan Singkat (FBVKS) diberikan kepada 90 negara yang mendapatkan bebas visa kunjungan singkat diharapkan mampu meningkatkan kunjungan wisman.

Keterkaitan antara industri pariwisata dengan devisa dalam upaya menjaga stabilitas nilai tukar rupiah tentu sangat erat dan saling mendukung satu sama lainnya. Pemerintah harus mampu menggenjot kedatangan wisman dengan berbagai upaya. Jika tidak, maka dikuatirkan dalam jangka waktu lama Indonesia 
semakin tidak dikenal oleh para pelancong elas dunia. Artinya, potensi pendapatan negara yang tidak membutuhkan modal besar menjadi hilang.

\section{Penutup}

a. Kesimpulan.

Pariwisata merupakan suatu kegiatan yang secara langsung menyentuh dan melibatkan masyarakat, sehingga membawa berbagai dampak terhadap masyarakat daerah tujuan wisata. Bahkan pariwisata dikatakan sebagai salah satu upaya memperoleh devisa bagi pemerintah Indonesia, maka untuk tahun 2019 ini menuju pariwisata 4.0 pemerintah segera mengimplementasikan dalam menyiapkan sumber daya manusia berkompenten untuk menyasar wisatawan millenial.

b. Saran.

Upaya mendorong peningkatan pertumbuhan pariwisata yang selama ini dijalankan seyogyanya selalu dijadikan bagian tidak terpisahkan dari kebijakan peningkatan devisa negara, sehingga perlu diintegrasikan kebijakan pariwisata dan devisa nasional dengan kebijakan nilai tukar supaya nilai tukar rupiah tetap kompetitif. 


\section{DAFTAR PUSTAKA}

Arief Yahya, “Gebyar Pesona Budaya Indonesia”, Republika, 22-2-2019.

Oka A.Yoeti, Pengantar Ilmu Pariwisata”, Bandung, PT.Angkasa, 1998.

Kompas, "Strategi Menyasar Pasar Millenial”, Maret 2019.

Noviani Karina Putri, "Memanfaatkan Media Digital untuk Kemajuan Pariwisata”, Warta Ekonomi, Edisi Kamis, 4/2018. 